\title{
Optimization of fermentation upstream parameters and immobilization of Corynebacterium glutamicum MH 20-22 B cells to enhance the production of L-lysine
}

\author{
Meerza Abdul Razak • Buddolla Viswanath
}

Received: 12 April 2014/ Accepted: 13 September 2014/Published online: 27 September 2014

(C) The Author(s) 2014. This article is published with open access at Springerlink.com

\begin{abstract}
L-Lysine is an essential amino acid with high commercial importance, as it has to be available in sufficient quantities in animal and human feeds to meet their nutritional requirement. As there is constant increase in L-lysine demand every year, to meet the increasing demand it is necessary to produce L-lysine in large scale. Generally, L-lysine is produced by batch fermentation. In the present investigation, different fermentation process parameters such as fermentation time, $\mathrm{pH}$, temperature, glucose concentration, airflow rate and aeration rate were studied to optimize the production of L-lysine by Corynebacterium glutamicum $\mathrm{MH}$ 20-22 B in a 5 L laboratory-scale stirred tank bioreactor. A comparative study of L-lysine production with free cells and immobilized cells of $C$. glutamicum MH 20-22 B was also investigated to determine whether free cells or immobilized cells were advantageous for production of L-lysine. In this way, optimized fermentation upstream parameters which produced the maximum yield of L-lysine were developed and it was also concluded from the present study that immobilized cells of $C$. glutamicum MH 20-22 B were more advantageous for L-lysine production as they yield more L-lysine compared to free cells of C. glutamicum MH 20-22 B. It was observed in the present study that the optimum values of fermentation time, $\mathrm{pH}$, temperature, glucose concentration, airflow rate and aeration rate were $96 \mathrm{~h}, 7.5,30{ }^{\circ} \mathrm{C}, 90 \mathrm{~g} / \mathrm{l}, 1.0 \mathrm{vvm}$ and $200 \mathrm{rpm}$, respectively, by immobilized cells, whereas
\end{abstract}

\section{A. Razak}

Natco Pharma Limited, Natco House, Road No. 2, Banjara Hills, Hyderabad 500 034, India

B. Viswanath $(\bowtie)$

Department of Virology, Sri Venkateswara University,

Tirupati 517502, AP, India

e-mail: buddolla@gmail.com in case of free cells the optimum values were $72 \mathrm{~h}, 7.5$, $30{ }^{\circ} \mathrm{C}, 80 \mathrm{~g} / \mathrm{l}, 1.25 \mathrm{vvm}$ and $300 \mathrm{rpm}$. Immobilized $C$. glutamicum MH 20-22 B cells exhibited greater L-lysine production of $31.58 \mathrm{~g} / \mathrm{l}$ than free cells which produced $26.34 \mathrm{~g} / \mathrm{l}$ of L-lysine.

Keywords L-Lysine - C. glutamicum - Immobilization * Upstream process parameters

\section{Introduction}

Amino acids have long played a vital role in both human and animal nutrition and health maintenance (Bercovici and Fuller 2007). With the advent of new applications and the steadily growing market demand of amino acids, their production technology has made an enormous progress during the second half of the twentieth century. Fermentation and enzymatic catalysis are the two biotechnological processes which posses both ecological and economical advantage and are the main reason for the spectacular growth of the amino acid industry. The feed amino acids L-lysine, DL-methionine, L-threonine, and L-tryptophan contribute the largest share $(56 \%)$ of the total amino acid market, approximately US\$ 4.5 billion (Leuchtenberger et al. 2005). Low-cost fermentation processes have been developed for different kinds of amino acids and the current rapid progress in biotechnology, including biochemical engineering technology, strain improvement along with downstream processing, indicates that the fermentation process is the key role in the amino acid industry. Over a period of time, fermentation technology has played a vital role and recently amino acids produced by fermentation processes are the main products of biotechnology in value and volume (Ikeda 2003).

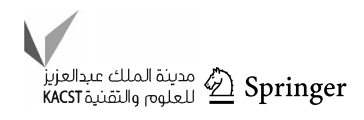


L-Lysine $\left(\mathrm{C}_{6} \mathrm{H}_{14} \mathrm{~N}_{2} \mathrm{O}_{2} ; \mathrm{MW}\right.$ 146.19) is one of the essential, commercial and important amino acid which is produced on large scale by the amino acid industry. L-lysine is generally produced in purity higher than $98.5 \%$ in stable and non-hygroscopic hydrochlorinated form (Fechter et al. 1997). L-Lysine has a number of applications in the food, pharmaceutical, feed milling and cosmetics industries, and its current price is approximately US\$3-4/kg. The production costs of L-lysine have been lowered because of continuous optimization of the fermentation process. $80 \%$ of lysine in the world market is synthesized by microbial fermentation and the remaining $20 \%$ by chemical synthesis. Thus, the scope for L-lysine production in the amino acid industry is more because of its increasing market demand (Anastassiadis 2007). The raw materials used in the fermentation process for the production of L-lysine are biologically and naturally available, and the by-products produced during L-lysine fermentation are non-toxic and have high commercial value. The microbes separated from the broth contain more than $50 \%$ of proteins, which are used in animal feed. Organic and inorganic nitrogen compounds, phosphorus compounds and potassium salts, which could be used as fertilizers, are also produced in the spent broth during L-lysine production (Anastassiadis 2007).

Microbial strains such as Brevibacterium lactofermentum (Fechter et al. 1997), Brevibacterium flavum (Ikeda 2003) and C. glutamicum (Anastassiadis 2007) have been used for the past 50 years for large-scale production of L-lysine, but the sole production organism for L-lysine is $C$. glutamicum and its subspecies. L-Lysine is produced by an aerobic fermentation process using $C$. glutamicum, which is a rod-shaped, fast-growing, non-sporulating, Grampositive and nonpathogenic coryneform bacterium $(\mathrm{Ki}-$ noshita et al. 1957; Udaka 1960). The ability of $C$. glutamicum to produce other amino acids, such as L-threonine (Nakayama and Kase 1974), L-methionine (Kase and Nakayama 1975), L-serine (Eggeling 2007), L-histidine (Araki et al. 1974), L-valine (Ruklisha et al. 2007), L-tryptophan (Ikeda 2006), L-phenylalanine and L-tyrosine (Ikeda and Katsumata 1992), L-leucine (Patek 2007) and L-isoleucine (Guillout et al. 2002), has made it an important organism in industrial biotechnology. Large-scale production of L-lysine by fermentation with $C$. glutamicum started in 1958 at Kyowa Hakko's plant in Japan. The biotechnological production of L-lysine has been constantly improved by fermentation process optimization and strain improvement (Pfefferle et al. 2003). Fermentation time, $\mathrm{pH}$, temperature, glucose concentration, airflow rate and aeration rate are the most important factors in fermentation processes. However, there have been very few reports on fermentation process optimization. Hence, the main objective of this paper is to study L-lysine production by fermentation of free and immobilized cells using different culture parameters.

\section{Materials and methods}

C. glutamicum MH 20-22 B, which is a leucine auxotroph, was employed throughout this study. C. glutamicum $\mathrm{MH}$ 20-22 B was donated by Professor Eggeling, Biotechnology Institute, Julich, Germany. It was cultured on agar slopes using nutrient agar medium containing peptone $(5 \mathrm{~g})$, beef extract (3 g), $\mathrm{NaCl}(5 \mathrm{~g})$, agar (15 g) and distilled water $(1,000 \mathrm{ml})$. The $\mathrm{pH}$ was maintained at 7.0 . The composition of the media used in the fermentation process was as follows:

Rich medium

Glucose (10 g), yeast extract $(10 \mathrm{~g})$, peptone $(10 \mathrm{~g}), \mathrm{NaCl}$ $(2.5 \mathrm{~g})$ and distilled water $(1.0 \mathrm{~L})$; the $\mathrm{pH}$ was maintained at 7.0 .

Inoculum medium

$\mathrm{CaCl}_{2} \cdot 2 \mathrm{H}_{2} \mathrm{O} \quad(1 \mathrm{~g}), \quad\left(\mathrm{NH}_{4}\right) \cdot 2 \mathrm{SO}_{4} \quad(30 \mathrm{~g}), \quad \mathrm{MgSO}_{4} \cdot 7 \mathrm{H}_{2} \mathrm{O}$ $(0.4 \mathrm{~g}), \mathrm{NaCl}(0.05 \mathrm{~g}), \mathrm{MnSO}_{4} \cdot \mathrm{H}_{2} \mathrm{O}(0.0076 \mathrm{~g}), \mathrm{FeSO}_{4}$. $7 \mathrm{H}_{2} \mathrm{O}(0.001 \mathrm{~g}), \mathrm{KH}_{2} \mathrm{PO}_{4}(0.5 \mathrm{~g}), \mathrm{K}_{2} \mathrm{HPO}_{4}(0.5 \mathrm{~g})$, Urea $(2 \mathrm{~g})$, yeast extract $(1 \mathrm{~g})$, peptone $(1 \mathrm{~g})$, D-glucose $(10 \mathrm{~g})$, thiamine $(0.2 \mathrm{mg})$, D-biotin $(0.5 \mathrm{mg})$ and distilled water $(1.0 \mathrm{~L})$; the $\mathrm{pH}$ was maintained at 7.0.

\section{Fermentation medium}

$\mathrm{CaCl}_{2} \cdot 2 \mathrm{H}_{2} \mathrm{O} \quad(1 \mathrm{~g}), \quad\left(\mathrm{NH}_{4}\right) \cdot 2 \mathrm{SO}_{4} \quad(30 \mathrm{~g}), \quad \mathrm{MgSO}_{4} \cdot 7 \mathrm{H}_{2} \mathrm{O}$ $(0.4 \mathrm{~g}), \mathrm{NaCl}(0.05 \mathrm{~g}), \mathrm{MnSO}_{4} \cdot \mathrm{H}_{2} \mathrm{O}(0.0076 \mathrm{~g}), \mathrm{FeSO}_{4}$. $7 \mathrm{H}_{2} \mathrm{O}(0.001 \mathrm{~g}), \mathrm{KH}_{2} \mathrm{PO}_{4}(1 \mathrm{~g}), \mathrm{K}_{2} \mathrm{HPO}_{4}(1 \mathrm{~g})$, urea $(2 \mathrm{~g})$, yeast extract $(1.5 \mathrm{~g})$, peptone $(2 \mathrm{~g})$, D-glucose $(150 \mathrm{~g})$, thiamine $(0.2 \mathrm{mg})$, D-biotin $(0.5 \mathrm{mg})$, L-serine $(0.1 \mathrm{mg})$ and distilled water $(1.0 \mathrm{~L})$; the $\mathrm{pH}$ was maintained at 7.0.

Fermentation procedure

C. glutamicum MH 20-22 B cells were cultured on a nutrient agar strain maintenance plate at $30{ }^{\circ} \mathrm{C}$ for $24 \mathrm{~h}$ and inoculated into $20 \mathrm{ml}$ of rich medium in a $250 \mathrm{ml}$ conical flask. After $24 \mathrm{~h}$ of cultivation in an orbital shaker with $120 \mathrm{rpm}$ at $30{ }^{\circ} \mathrm{C}$, the seed broth was transferred to $180 \mathrm{ml}$ of inoculum media in an Erlenmeyer flask and maintained in an orbital shaker for $40 \mathrm{~h}$ at $120 \mathrm{rpm}$ and $30{ }^{\circ} \mathrm{C}$. This was then used to inoculate the fermentation medium in the stirred tank bioreactor. Batch fermentation experiments were carried out at different parameters to optimize the upstream parameters for free cells and immobilized cells. 
Immobilization method

\section{Growth medium composition}

Glucose $(2 \mathrm{~g})$, beef extract ( $1 \mathrm{~g})$, Bacto Peptone (1 g), $\mathrm{NaCl}(0.25 \mathrm{~g})$, agar $(2 \mathrm{~g})$ and distilled water $(100 \mathrm{ml})$ were maintained at $\mathrm{pH}$ 7.0. Agar slants of C. glutamicum $\mathrm{MH}$ 20-22 B which were grown for $24 \mathrm{~h}$ were used to inoculate $50 \mathrm{ml}$ of growth medium (and kept on shaker for $48 \mathrm{~h}$ $(150 \mathrm{rpm})$ at $30{ }^{\circ} \mathrm{C} .100 \mathrm{ml}$ of $72 \mathrm{~h}$-old culture was used to prepare immobilized beads of calcium alginate. $15 \%$ volume of beads were employed throughout this study. Immobilization of $C$. glutamicum $\mathrm{MH}$ 20-22 B cells was done in strict aseptic conditions. Gluteraldehyde entrapment method using cross-linked calcium alginate was used to immobilize $C$. glutamicum MH 20-22 B cells (Jetty et al. 2005; Marek et al. 1985). $100 \mu$ l gluteraldehyde and $3 \%$ sodium alginate were thoroughly mixed with $0.06 \%$ cells on dry cell weight basis (DCW) (w/v) to get uniform suspension. This uniform suspension was transferred into $0.2 \mathrm{M} \mathrm{CaCl}_{2}$ solution using a peristaltic pump through a cut micropipette tip (or) orifice. The curing of the formed beads was done by incubating in $0.2 \mathrm{M} \mathrm{CaCl}_{2}$ solution for $24 \mathrm{~h}$. The beads were washed twice with sterile saline solution $(0.9 \% \mathrm{NaCl}$ solution $(\mathrm{w} / \mathrm{v}))$ and preserved at $4{ }^{\circ} \mathrm{C}$ in saline solution for further use.

\section{Sterilization of the stirred tank bioreactor}

Initially, all reactor parts were separated. All parts were washed with distilled water thoroughly and again with acetone before sterilization. After washing with distilled water, all the above parts were wrapped with aluminum foil before placing in the autoclave. All these accessories were kept in the autoclave, which was operated at a temperature of $120{ }^{\circ} \mathrm{C}$ and a pressure of 15 psi for a period of $20 \mathrm{~min}$.

Fermentation studies

Batch or fed-batch processes are employed for the commercial production of amino acids. In batch operations all of the nutrients are added at the beginning. Moreover, in batch fermentations microorganisms grows until one or more of essential nutrients get exhausted or until fermentation conditions such as oxygen limitation, $\mathrm{pH}$ decrease and product inhibition become unfavorable. In this present investigation, fermentation experiments with free cells and immobilized cells of C. glutamicum MH 20-22 B were conducted with different fermentation parameters at batch mode using a sterilized continuous stirred tank bioreactor of $5 \mathrm{~L}$ capacity. For experiments with immobilized cells of C. glutamicum, a fermentation medium containing $60 \mathrm{~g}$ of immobilized beads (15\%) was used throughout the experiments. Beads containing $3.0-3.5 \mathrm{~mm}$ range of diameter were used. Different parameters with different variations were studied, and variations in the particular parameter were made as per the previous experiments and literature.

Analytical methods

L-Lysine in the supernatant fluid was quantitatively estimated by the acidic ninhydrin method (Chinard 1952). Throughout the study, the glucose concentration was estimated by the anthrone method (Morris 1948; Neish 1952). The dry cell weight (Biomass) was determined (Kim et al. 1981).

\section{Results and discussions}

The present report describes the optimization of fermentation parameters for L-lysine production by $C$. glutamicum MH 20-22 B. The continuous batch fermentation described in this study also facilitated the analysis of the various parameters affecting L-lysine fermentation. Earlier, many investigators have reported about multistage continuous fermentation processes and their difficulties in running continuous L-lysine production systems (Becker 1982; Michalski et al. 1984). To determine the suitable conditions for L-lysine production by free and immobilized cells of $C$. glutamicum in a stirred tank bioreactor, the parameters investigated are L-lysine concentration, biomass concentration, residual glucose concentration and glucose utilized with variations in fermentation time, temperature, $\mathrm{pH}$, substrate concentration (glucose), aeration and agitation rate.

Effect of fermentation time on L-lysine production by free cells

The effect of fermentation time on L-lysine production by free cells of $C$. glutamicum MH 20-22 B was studied maintaining the operating conditions as temperature of $28{ }^{\circ} \mathrm{C}, \mathrm{pH} 7.0$, air flow rate $1.5 \mathrm{vvm}$, agitation rate $300 \mathrm{rpm}$ and glucose concentration 100 (g/l). It was analyzed from Fig. 1 that as the fermentation time increased, the concentration of the residual glucose decreased from 34.13 to $18.80 \mathrm{~g} / \mathrm{l}$ between 48 and $72 \mathrm{~h}$ and the product concentration also increased from 12.3 to $18.7 \mathrm{~g} / \mathrm{l}$ with biomass concentration from 6.11 to $9.1 \mathrm{~g} / \mathrm{l}$. Similar studies were carried out by Ekwealor and Obeta (2005) for the production of lysine using Bacillus megaterium free cells. As the fermentation proceeded further, the glucose consumption and L-lysine production increased and reached 
Fig. 1 Effect of fermentation time on L-lysine production by free cells

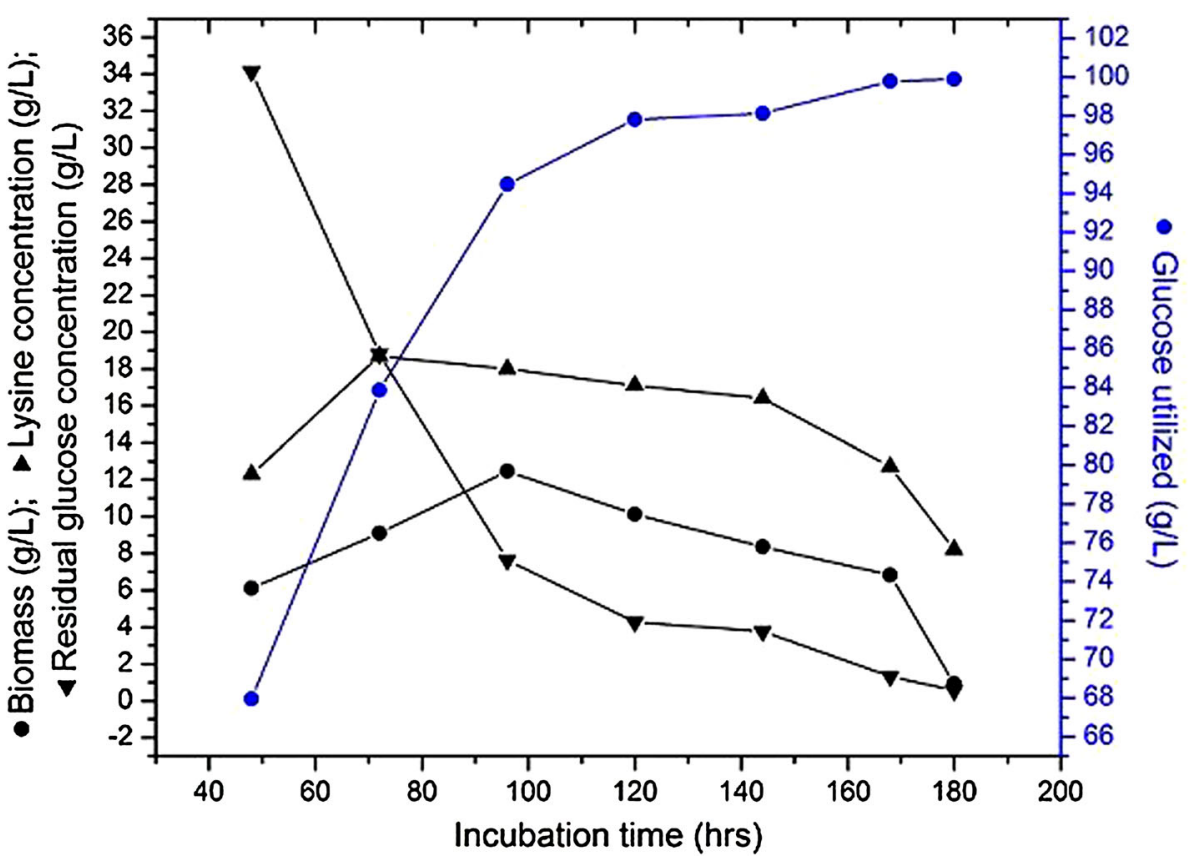

the maximum at $72 \mathrm{~h}$, with increased sugar utilization rate and maximum L-lysine concentration of $18.7 \mathrm{~g} / \mathrm{l}$ being observed (Fig. 1). After $72 \mathrm{~h}$, the maximum product achieved a downward trend and L-lysine concentration and yields decreased, in spite of the increase in fermentation time due to less availability of nutrients. So a fermentation time of $72 \mathrm{~h}$ was most suitable for the production of L-lysine using C. glutamicum MH 20-22 B free cells. Hadj Sassi et al. (1988) studied the yield of L-lysine (Yp/s) by $C$. glutamicum in a fed-batch reactor using free cells, and the maximum yield was $0.21(\mathrm{~g} / \mathrm{g})$.

Effect of temperature on L-lysine production by free cells

The growth rate of bacterial microorganisms is strongly dependent on temperature during fermentation which changes the whole metabolism. In this present study, an attempt has been made to study the effect of different temperature ranges $\left(27-32{ }^{\circ} \mathrm{C}\right)$ on $\mathrm{L}$-lysine production carried out in a stirred tank reactor. The temperature profile on L-lysine production was done using C. glutamicum MH 20-22 B free cells under operating conditions such as fermentation time of $72 \mathrm{~h}, \mathrm{pH} 7.0$, air flow rate $1.5 \mathrm{vvm}$, agitation rate $300 \mathrm{rpm}$ and glucose concentration $100 \mathrm{~g} / \mathrm{l}$. Any change in the temperature can alter the substrate utilization rate of microorganism, which leads to unbalanced nutrients in the medium with respect to the growth rate of the $C$. glutamicum cells. If any of the crucial nutrients is exhausted soon or unused, this can make the growth in culture from balanced to unbalanced
Table 1 Effect of temperature on L-lysine production by free cells

\begin{tabular}{llllll}
\hline Sl. no. & $\begin{array}{l}\text { Temperature } \\
\left({ }^{\circ} \mathrm{C}\right)\end{array}$ & $\begin{array}{l}\text { Lysine } \\
\text { conc. } \\
(p)(\mathrm{g} / \mathrm{l})\end{array}$ & $\begin{array}{l}\text { Biomass } \\
(x)(\mathrm{g} / \mathrm{l})\end{array}$ & $\begin{array}{l}\text { Residual } \\
\text { glucose } \\
\text { conc. }(\mathrm{g} / \mathrm{l})\end{array}$ & $\begin{array}{l}\text { Glucose } \\
\text { utilized } \\
(s)(\mathrm{g} / \mathrm{l})\end{array}$ \\
\hline 1 & 27 & 14.6 & 13.35 & 8.54 & 93.47 \\
2 & 28 & 18.4 & 14.78 & 5.21 & 94.78 \\
3 & 29 & 19.6 & 15.67 & 4.32 & 97.77 \\
4 & 30 & 21.31 & 18.24 & 2.65 & 99.34 \\
5 & 31 & 19.7 & 16.52 & 3.53 & 98.56 \\
6 & 32 & 17.9 & 14.43 & 5.25 & 96.84 \\
\hline
\end{tabular}

and results in performance change. At $30{ }^{\circ} \mathrm{C}$, maximum L-lysine concentration of $21.31(\mathrm{~g} / \mathrm{l})$ was obtained along with $18.24 \mathrm{~g} / \mathrm{l}$ of maximum biomass (Table 1). Glucose utilization was also high at $30^{\circ} \mathrm{C}$. An increase in temperature resulted in decreased productivity, which suggested that a small increase in temperature has a profound effect on cellular activities, such as repression of metabolic enzymes. Hilliger et al. (1984) observed the influence of temperature as one of the major fermentation parameters on growth and L-lysine formation by $C$. glutamicum. They studied L-lysine production at different temperatures which showed that biomass and L-lysine concentration was high at $30^{\circ} \mathrm{C}$, whereby temperatures exceeding $32{ }^{\circ} \mathrm{C}$ reduced the specific L-lysine formation rate and the substrate conversion yield coefficient. Hence, a temperature of $30{ }^{\circ} \mathrm{C}$ was optimum temperature for L-lysine fermentation by both free and immobilized cells of C. glutamicum MH 20-22 B. 
Table 2 Effect of $\mathrm{pH}$ on L-lysine production by free cells

\begin{tabular}{llllll}
\hline S1. no & $\mathrm{pH}$ & $\begin{array}{l}\text { Lysine } \\
\text { conc. } \\
(p)(\mathrm{g} / \mathrm{l})\end{array}$ & $\begin{array}{l}\text { Biomass } \\
(x)(\mathrm{g} / \mathrm{l})\end{array}$ & $\begin{array}{l}\text { Residual } \\
\text { glucose } \\
\text { conc. }(\mathrm{g} / \mathrm{l})\end{array}$ & $\begin{array}{l}\text { Glucose } \\
\text { utilized } \\
(s)(\mathrm{g} / \mathrm{l})\end{array}$ \\
\hline 1 & 6 & 12.3 & 13.62 & 8.89 & 93.02 \\
2 & 6.5 & 14.4 & 14.53 & 5.63 & 96.46 \\
3 & 7 & 19.42 & 14.87 & 2.53 & 97.66 \\
4 & 7.5 & 22.58 & 17.85 & 0.52 & 99.27 \\
5 & 8 & 18.57 & 13.34 & 3.29 & 98.08 \\
6 & 8.5 & 16.52 & 12.98 & 4.53 & 97.56 \\
\hline
\end{tabular}

Effect of $\mathrm{pH}$ on L-lysine production by free cells

In microbial fermentations, $\mathrm{pH}$ is a very important and strongly influencing factor. Basic compounds, such as ammonium hydroxide, potassium hydroxide, sodium hydroxide, calcium carbonate, ammonia and gaseous ammonia and urea, inorganic acid compounds such as sulfuric or phosphoric acid and organic acids are utilized for controlling $\mathrm{pH}$ in L-lysine cultures ranging from 5.0 to 9.0 (Nakamura et al. 2000). The effect of $\mathrm{pH}$ was found to be a very significant parameter in L-lysine yield. The $\mathrm{pH}$ effect on L-lysine production was investigated under operating conditions such as fermentation time of $72 \mathrm{~h}$, temperature of $30^{\circ} \mathrm{C}$, air flow rate of $1.5 \mathrm{vvm}$, agitation rate of $300 \mathrm{rpm}$ and glucose concentration rate of $100 \mathrm{~g} / \mathrm{l}$. From Table 2, it may be analyzed that the optimum $\mathrm{pH}$ for C. glutamicum MH 20-22 B free cells is 7.5, with the maximum lysine concentration of $22.58(\mathrm{~g} / \mathrm{l})$. At $7.5 \mathrm{pH}$ the biomass production was also high at $17.85 \mathrm{~g} / \mathrm{l}$. Broer et al. (1993) also reported that the optimum $\mathrm{pH}$ for maximum velocity transport of $C$. glutamicum was 7.4-7.8. To maintain optimal $\mathrm{pH}$, reagents such as calcium carbonate must be added to the culture medium at the beginning of fermentation. Thus, calcium carbonate was used as an internal neutralizing agent. Though the $\mathrm{pH}$ of the fermenter was automatically controlled by ammonia water, a small amount of $\mathrm{CaCO}_{3}$ must be added (Wang et al. 1991). It eliminates the lag phase of cell growth, thereby shortening fermentation time. Therefore 7.0 was considered as an optimum $\mathrm{pH}$ for all the experiments.

Effect of glucose concentration on L-lysine production by free cells

In fermentation, the cell concentration and substrate concentration play major roles in the overall performance of the process for L-lysine production. The cells use available substrate immediately if the process conditions in the reactor are favorable. The viability and growth of the cells are very much dependent on the substrate availability in the reactor. L-Lysine-producing bacteria can utilize various
Table 3 Effect of glucose concentration on L-lysine production by free cells

\begin{tabular}{llllll}
\hline Sl. no. & $\begin{array}{l}\text { Glucose } \\
\text { concentration } \\
(\mathrm{g} / \mathrm{l})\end{array}$ & $\begin{array}{l}\text { Lysine } \\
\text { conc. } \\
(p)(\mathrm{g} / \mathrm{l})\end{array}$ & $\begin{array}{l}\text { Biomass } \\
(x)(\mathrm{g} / \mathrm{l})\end{array}$ & $\begin{array}{l}\text { Residual } \\
\text { glucose } \\
\text { conc. }(\mathrm{g} / \mathrm{l})\end{array}$ & $\begin{array}{l}\text { Glucose } \\
\text { utilized } \\
(s)(\mathrm{g} / \mathrm{l})\end{array}$ \\
\hline 1 & 70 & 14.7 & 5.13 & 3.62 & 68.47 \\
2 & 80 & 20.1 & 9.35 & 4.54 & 67.67 \\
3 & 90 & 19.89 & 16.59 & 6.08 & 85.29 \\
4 & 100 & 18.1 & 17.23 & 10.57 & 91.52 \\
5 & 110 & 13.9 & 17.98 & 14.64 & 97.45 \\
6 & 120 & 11.5 & 18.32 & 18.25 & 99.48 \\
\hline
\end{tabular}

carbon sources, such as glucose, fructose, sucrose and maltose. The effect of substrate on the L-lysine yield was expressed on the basis of lysine produced per unit substrate consumed. The effect of glucose concentration on L-lysine production by free cells of $C$. glutamicum $\mathrm{MH}$ 20-22 B was studied by carrying fermentation under conditions of $\mathrm{pH}$ 7.5 , fermentation time $72 \mathrm{~h}$, temperature $30^{\circ} \mathrm{C}$, air flow rate $1.5 \mathrm{vvm}$, agitation rate $300 \mathrm{rpm}$ and different ranges of glucose concentrations of $70,80,90,100,110$ and $120(\mathrm{~g} / \mathrm{l})$.

Glucose concentration on L-lysine production was investigated by Hirose and Shibai (1985) and it was found that higher concentration of glucose inhibited bacterial growth along with low yield. For this purpose, the effects of different concentrations of glucose on L-lysine production were examined. Different L-lysine batch fermentations were conducted at different initial glucose concentrations. From different batches, it was apparent that lysine production was cell growth associated and this was clearly confirmed. From Table 3 the maximum L-lysine concentration of $20.1(\mathrm{~g} / \mathrm{l})$ is observed at glucose concentration of $80 \mathrm{~g} / 1$ for C. glutamicum MH 20-22 B free cells and any excessive substrate concentration present in the fermentation broth leads to reduction in the product concentration because of substrate inhibition. (Hadj Sassi et al. 1988) reported that the initial concentration of glucose influenced the production of L-lysine by Corynebacterium Sp. in batch culture and found that the specific production rate was obtained at $65 \mathrm{~g} / \mathrm{l}$ of glucose. However, it was observed that $\mathrm{pH}$ and substrate concentration had significant effect in comparison to temperature.

Effect of airflow rate on L-lysine production by free cells

The air supply in submerged cultures is known to have an important influence on microbial production of amino acids (Akashi et al. 1979). Thus, oxygen has been shown to play an important and crucial role in the regulation of both intermediary metabolism and biomass formation coupled 
Table 4 Effect of airflow rate on L-lysine production by free cells

\begin{tabular}{llllll}
\hline S1. no. & $\begin{array}{l}\text { Air flow } \\
\text { rate } \\
(\mathrm{vvm})\end{array}$ & $\begin{array}{l}\text { Lysine } \\
\text { conc. } \\
(p)(\mathrm{g} / \mathrm{l})\end{array}$ & $\begin{array}{l}\text { Biomass } \\
(x)(\mathrm{g} / \mathrm{l})\end{array}$ & $\begin{array}{l}\text { Residual } \\
\text { glucose } \\
\text { conc. }(\mathrm{g} / \mathrm{l})\end{array}$ & $\begin{array}{l}\text { Glucose } \\
\text { utilized } \\
(s)(\mathrm{g} / \mathrm{l})\end{array}$ \\
\hline 1 & 0.25 & 11.54 & 09.76 & 7.31 & 74.96 \\
2 & 0.5 & 15.47 & 12.37 & 5.35 & 76.74 \\
3 & 0.75 & 16.26 & 16.54 & 4.47 & 77.62 \\
4 & 1 & 19.53 & 18.28 & 3.33 & 78.76 \\
5 & 1.25 & 20.54 & 19.34 & 1.57 & 80.66 \\
6 & 1.5 & 18.43 & 17.74 & 2.56 & 78.67 \\
\hline
\end{tabular}

with alteration of L-lysine synthesis and with a change of L-lysine yield, respectively. To find the optimum value of air flow rate for free cells of C. glutamicum MH 20-22 B, experimental studies were conducted in a batch-stirred tank reactor in the bioreactor under conditions of $\mathrm{pH} 7.5$, fermentation time $72 \mathrm{~h}$, temperature $30{ }^{\circ} \mathrm{C}$, agitation rate $300 \mathrm{rpm}$, glucose concentration $80 \mathrm{~g} / \mathrm{l}$ and the aeration rate maintained at different ranges from 0.25 to 1.5 . Table 4 shows the characteristic batches of L-lysine fermentation at a range of $0.25-1.5$ volume air per volume of medium per minute (vvm). The best air flow rate for L-lysine production by free cells was $1.25 \mathrm{vvm}$, the product concentration was $20.54 \mathrm{~g} / \mathrm{l}$ and the biomass productivity was $19.34 \mathrm{~g} / \mathrm{l}$. Glucose utilized was $80.66 \mathrm{~g} / \mathrm{l}$ at $1.25 \mathrm{vvm}$. So $1.25 \mathrm{vvm}$ was considered as the optimum airflow rate for $C$. glutamicum MH 20-22 B free cells. Wang et al. (1991) performed fermentation of L-lysine on a rotary shaker at $200 \mathrm{rpm}$ and suggested that the optimum air flow rate of L-lysine production was $1.0 \mathrm{vvm}$ or above $1.0 \mathrm{vvm}$, approximately.

Effect of agitation rate on L-lysine production by free cells

Agitation and aeration in a stirred tank bioreactor always cause foaming. Excess foaming forces the broth out of the bioreactor and contaminates the system quickly. Optimum aeration must be maintained, as agitation minimizes foaming and maximizes the specific production rate. In the bioreactor, the fermentation medium was agitated to provide homogeneity across the vessel. L-lysine production at different agitation rates of 100, 150, 200, 300, 350 and $400 \mathrm{rpm}$ and under different conditions such as $\mathrm{pH} 7.5$, fermentation time $72 \mathrm{~h}$, temperature $30^{\circ} \mathrm{C}$, aeration rate $1.25 \mathrm{vvm}$ and glucose concentration $80 \mathrm{~g} / 1$ was examined to find out the optimum agitation rate for L-lysine production by free cells of $C$. glutamicum MH 20-22 B. From Table 5, we can observe that the maximum L-lysine concentration is $26.34 \mathrm{~g} / \mathrm{l}$ and the biomass is $17.13 \mathrm{~g} / \mathrm{l}$ at $300 \mathrm{rpm}$. Therefore, the optimum agitation rate for L-lysine
Table 5 Effect of agitation rate on L-lysine production by free cells

\begin{tabular}{llllll}
\hline S1. no. & $\begin{array}{l}\text { Agitation } \\
\text { rate }(\mathrm{rpm})\end{array}$ & $\begin{array}{l}\text { Lysine } \\
\text { conc. } \\
(p)(\mathrm{g} / \mathrm{l})\end{array}$ & $\begin{array}{l}\text { Biomass } \\
(x)(\mathrm{g} / \mathrm{l})\end{array}$ & $\begin{array}{l}\text { Residual } \\
\text { glucose } \\
\text { conc. }(\mathrm{g} / \mathrm{l})\end{array}$ & $\begin{array}{l}\text { Glucose } \\
\text { utilized } \\
(s)(\mathrm{g} / \mathrm{l})\end{array}$ \\
\hline 1 & 100 & 19.58 & 11.78 & 7.54 & 94.55 \\
2 & 150 & 22.73 & 14.65 & 6.50 & 95.59 \\
3 & 200 & 23.37 & 15.98 & 4.23 & 97.86 \\
4 & 250 & 25.95 & 16.35 & 3.56 & 98.53 \\
5 & 300 & 26.34 & 17.13 & 2.51 & 99.58 \\
6 & 350 & 23.85 & 14.43 & 3.48 & 98.16 \\
7 & 400 & 22.39 & 15.72 & 5.67 & 96.32 \\
\hline
\end{tabular}

production was $300 \mathrm{rpm}$ for free cells. Shah et al. (2002) studied the influence of dilution in the range between 50 and $300 \mathrm{rpm}$ and concluded that after $200 \mathrm{rpm}$ L-lysine production was levelled off.

Production of L-lysine by immobilized cells of C. Glutamicum

Effect of fermentation time on L-lysine production by immobilized cells

Studies on the effect of fermentation time on L-lysine production by immobilized $C$. glutamicum $\mathrm{MH}$ 20-22 B cells were carried out under different fermentation conditions, such as temperature $28^{\circ} \mathrm{C}, \mathrm{pH} 7.0$, air flow rate $1.5 \mathrm{vvm}$, agitation rate $300 \mathrm{rpm}$ and glucose concentration $100(\mathrm{~g} / \mathrm{l})$. From Fig. 2, it may be analyzed that L-lysine concentration is relatively low over the first $2(48 \mathrm{~h})$ days. L-lysine accumulation was $20.1 \mathrm{~g} / 1$ at $72 \mathrm{~h}$ and later increased to $23.4 \mathrm{~g} / \mathrm{l}$ at $96 \mathrm{~h}$. The biomass concentration was $15.07 \mathrm{~g} / \mathrm{l}$ at $96 \mathrm{~h}$. After $96 \mathrm{~h}$, an important observation was the lower glucose concentration of $10.15 \mathrm{~g} / \mathrm{l}$, which further decreased as the fermentation process proceeded. Llysine production decreased due to the depletion of nutrients in the fermentation medium. The results presented in Fig. 2 show that L-lysine production is good at $96 \mathrm{~h}$, which is the best fermentation time for the production of L-lysine by immobilized cells of C. glutamicum MH 20-22 B.

\section{Effect of temperature on L-lysine production} by immobilized cells

The effect of temperature on L-lysine production by immobilized cells of C. glutamicum $\mathrm{MH}$ 20-22 B was studied under different operating conditions such as fer-

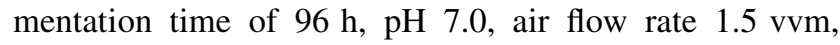
agitation rate $300 \mathrm{rpm}$ and glucose concentration $100 \mathrm{~g} / \mathrm{l}$. The results from Table 6 show that L-lysine concentration of $24.45 \mathrm{~g} / \mathrm{l}$, biomass of $19.45 \mathrm{~g} / \mathrm{l}$ and glucose utilization of 
Fig. 2 Effect of fermentation time on L-lysine production by immobilized cells

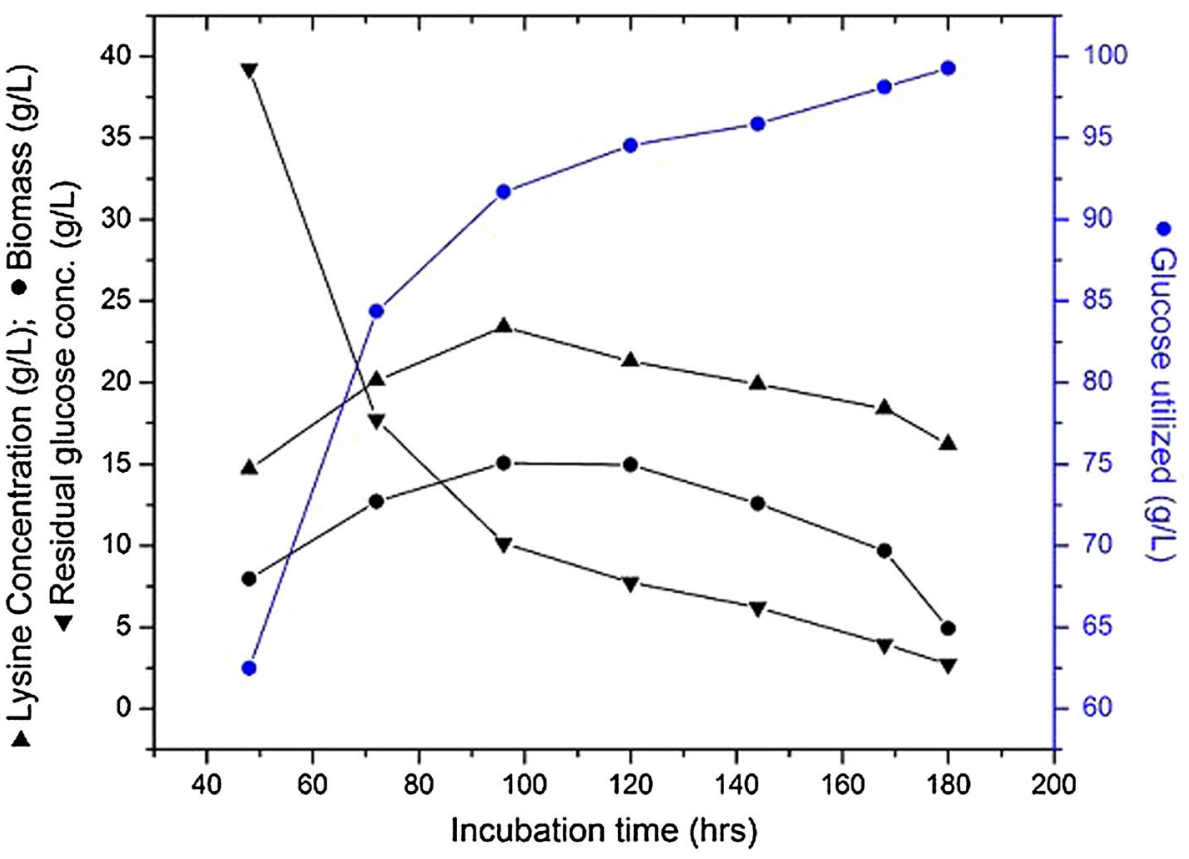

Table 6 Effect of temperature on L-lysine production by immobilized cells

\begin{tabular}{llllll}
\hline Sl. no. & $\begin{array}{l}\text { Temperature } \\
\left({ }^{\circ} \mathrm{C}\right)\end{array}$ & $\begin{array}{l}\text { Lysine } \\
\text { conc. } \\
(p)(\mathrm{g} / \mathrm{l})\end{array}$ & $\begin{array}{l}\text { Biomass } \\
(x)(\mathrm{g} / \mathrm{l})\end{array}$ & $\begin{array}{l}\text { Residual } \\
\text { glucose } \\
\text { conc. }(\mathrm{g} / \mathrm{l})\end{array}$ & $\begin{array}{l}\text { Glucose } \\
\text { utilized } \\
(s)(\mathrm{g} / \mathrm{l})\end{array}$ \\
\hline 1 & 27 & 17.89 & 15.15 & 12.33 & 89.76 \\
2 & 28 & 21.74 & 15.99 & 9.64 & 92.45 \\
3 & 29 & 22.33 & 16.79 & 8.61 & 93.48 \\
4 & 30 & 24.45 & 19.45 & 6.42 & 95.67 \\
5 & 31 & 23.20 & 18.82 & 4.66 & 97.43 \\
6 & 32 & 21.74 & 16.44 & 2.68 & 99.41 \\
\hline
\end{tabular}

$95.67 \mathrm{~g} / \mathrm{l}$, which were maximum compared to all temperatures, were observed at $30{ }^{\circ} \mathrm{C}$. Therefore, $30{ }^{\circ} \mathrm{C}$ temperature was most suitable for the production of L-lysine by $C$. glutamicum MH 20-22 B. The downtrend of residual glucose as the temperature increases can be seen in Table 6 . After $30{ }^{\circ} \mathrm{C}$, the L-lysine and biomass concentrations were decreased. Therefore, $30^{\circ} \mathrm{C}$ was the optimum temperature for L-lysine production by immobilized cells of C. $\mathrm{glu}$ tamicum MH 20-22 B.

\section{Effect of $\mathrm{pH}$ on L-lysine production by immobilized cells}

The growth rate of microorganism is usually very sensitive to variation in $\mathrm{pH}$. Furthermore, the process of growth changes the $\mathrm{pH}$ of the medium; therefore, the effect of different $\mathrm{pH}$ values on L-lysine production was examined in a stirred tank bioreactor. The $\mathrm{pH}$ profile of immobilized cells of C. glutamicum MH 20-22 B was studied by carrying fermentation under conditions such as fermentation
Table 7 Effect of $\mathrm{pH}$ on L-lysine production by immobilized cells

\begin{tabular}{llllll}
\hline Sl. no & $\mathrm{pH}$ & $\begin{array}{l}\text { Lysine } \\
\text { conc. } \\
(p)(\mathrm{g} / \mathrm{l})\end{array}$ & $\begin{array}{l}\text { Biomass } \\
(x)(\mathrm{g} / \mathrm{l})\end{array}$ & $\begin{array}{l}\text { Residual } \\
\text { glucose } \\
\text { conc. }(\mathrm{g} / \mathrm{l})\end{array}$ & $\begin{array}{l}\text { Glucose } \\
\text { utilized } \\
(s)(\mathrm{g} / \mathrm{l})\end{array}$ \\
\hline 1 & 6 & 14.69 & 15.47 & 12.86 & 89.23 \\
2 & 6.5 & 19.9 & 18.68 & 10.44 & 91.65 \\
3 & 7 & 21.78 & 19.33 & 7.34 & 94.75 \\
4 & 7.5 & 25.62 & 20.42 & 5.60 & 96.49 \\
5 & 8 & 21.71 & 17.53 & 4.41 & 97.68 \\
6 & 8.5 & 19.7 & 15.62 & 2.68 & 99.41 \\
\hline
\end{tabular}

time of $96 \mathrm{~h}$, temperature $30{ }^{\circ} \mathrm{C}$, air flow rate $1.5 \mathrm{vvm}$, agitation rate $300 \mathrm{rpm}$ and glucose concentration $100 \mathrm{~g} / \mathrm{l}$. The $\mathrm{pH}$ ranges were maintained from 6 to 8.5. The different $\mathrm{pH}$ values $(6-8.5)$ of the production medium were adjusted with $2 \mathrm{M} \mathrm{HCl}$ and $1 \mathrm{M} \mathrm{NaOH}$. Table 7 shows that the maximum L-lysine concentration of $25.62(\mathrm{~g} / \mathrm{l})$ and biomass of $20.42(\mathrm{~g} / \mathrm{l})$ were obtained at $\mathrm{pH}$ of 7.5 for immobilized cells of $C$. glutamicum MH 20-22 B. Table 7 also shows that as the $\mathrm{pH}$ increases, the residual glucose concentration decreases. When compared with all $\mathrm{pH}$ ranges, 7.5 was the best $\mathrm{pH}$ for $\mathrm{L}$-lysine production with immobilized cells.

\section{Effect of glucose concentration on L-lysine production} by immobilized cells

In the bioreactor, the cell concentration and glucose concentration play a major role in the overall performance of the process for L-lysine production. The cells use available glucose immediately if the process conditions in the reactor 
Table 8 Effect of glucose concentration on L-lysine production by immobilized cells

\begin{tabular}{llllll}
\hline Sl. no & $\begin{array}{l}\text { Substrate } \\
\text { conc. }(\mathrm{g} / \mathrm{l})\end{array}$ & $\begin{array}{l}\text { Lysine } \\
\text { conc. } \\
(p)(\mathrm{g} / \mathrm{l})\end{array}$ & $\begin{array}{l}\text { Biomass } \\
(x)(\mathrm{g} / \mathrm{l})\end{array}$ & $\begin{array}{l}\text { Residual } \\
\text { glucose } \\
\text { conc. }(\mathrm{g} / \mathrm{l})\end{array}$ & $\begin{array}{l}\text { Glucose } \\
\text { utilized } \\
(s)(\mathrm{g} / \mathrm{l})\end{array}$ \\
\hline 1 & 70 & 18.5 & 7.93 & 4.61 & 67.48 \\
2 & 80 & 21.10 & 11.38 & 6.66 & 75.43 \\
3 & 90 & 26.59 & 19.68 & 7.47 & 84.62 \\
4 & 100 & 23.7 & 18.64 & 12.33 & 89.76 \\
5 & 110 & 20.10 & 17.46 & 16.85 & 97.24 \\
6 & 120 & 17.5 & 16.64 & 20.66 & 99.34 \\
\hline
\end{tabular}

are favorable. The viability and growth of the cell are very much dependent on the glucose availability in the bioreactor. For this purpose, different glucose concentrations [70, 80, 90, 100, 110 and $120(\mathrm{~g} / \mathrm{l})]$ were employed under different conditions such as $\mathrm{pH} 7.5$, fermentation time $96 \mathrm{~h}$, temperature $30{ }^{\circ} \mathrm{C}$, air flow rate $1.5 \mathrm{vvm}$ and agitation rate $300 \mathrm{rpm}$ to determine its effect on L-lysine production. The maximum concentrations of L-lysine of $26.59 \mathrm{~g} / \mathrm{l}$ and biomass of $19.68 \mathrm{~g} / \mathrm{l}$ were obtained at $90 \mathrm{~g} / \mathrm{l}$ glucose concentration in spite of low residual concentration (Table 8). Glucose concentration of $90 \mathrm{~g} / \mathrm{l}$ was found to be effective in terms of L-lysine production with immobilized cells of $C$. glutamicum MH 20-22 B.

\section{Effect of aeration rate on L-lysine production by immobilized cells}

The oxygen supply is greatly vital for the fermentation process. Oxygen, an extremely important nutrient, is usually supplied to the reactor by an air pump. Experimental studies were conducted in a batch-stirred tank reactor to find the optimum value of air flow rate for $C$. glutamicum $\mathrm{MH} 20-22 \mathrm{~B}$ in the bioreactor under conditions of $\mathrm{pH} 7.5$, fermentation time $96 \mathrm{~h}$, temperature $30{ }^{\circ} \mathrm{C}$, agitation rate $300 \mathrm{rpm}$, glucose concentration $90 \mathrm{~g} / \mathrm{l}$ and the aeration rate maintained at different ranges from 0.25 to 1.5 . The maximum concentrations of L-lysine of $26.85 \mathrm{~g} / \mathrm{l}$ and biomass of $20.93 \mathrm{~g} / \mathrm{l}$ were obtained at an optimum air flow rate of $1.0 \mathrm{vvm}$ for stirred tank bioreactor (Table 9). The maximum product concentration, biomass and glucose utilized were good at the flow rate of $1.0 \mathrm{vvm}$. Therefore, the optimum air flow rate for L-lysine production was found to be $1.0 \mathrm{vvm}$.

\section{Effect of agitation rate on L-lysine production}

by immobilized cells

Experimental studies to know the agitation profile of immobilized cells of $C$. glutamicum MH 20-22 B for better production of L-lysine were done by carrying out fermentation under different conditions such as $\mathrm{pH} 7.5$, fermentation time $96 \mathrm{~h}$, temperature $30^{\circ} \mathrm{C}$, aeration rate $1.0 \mathrm{vvm}$, glucose concentration $90 \mathrm{~g} / \mathrm{l}$ and the agitation varied from ranges 100 to 400 . In the bioreactor, a stirrer is present to maintain uniform composition throughout the vessel. Maximum L-lysine concentration and yield observed at $200 \mathrm{rpm}$ were $31.58 \mathrm{~g} / \mathrm{l}$ and biomass of $17.72 \mathrm{~g} / \mathrm{l}$, respectively (Table 10). Therefore, the optimum agitation rate for L-lysine production was $200 \mathrm{rpm}$ for

Table 9 Effect of aeration rate on L-lysine production by immobilized cells

\begin{tabular}{llllll}
\hline S1. no & $\begin{array}{l}\text { Aeration } \\
\text { rate } \\
(\mathrm{vvm})\end{array}$ & $\begin{array}{l}\text { Lysine } \\
\text { conc. } \\
(p)(\mathrm{g} / \mathrm{l})\end{array}$ & $\begin{array}{l}\text { Biomass } \\
(x)(\mathrm{g} / \mathrm{l})\end{array}$ & $\begin{array}{l}\text { Residual } \\
\text { glucose } \\
\text { conc. }(\mathrm{g} / \mathrm{l})\end{array}$ & $\begin{array}{l}\text { Glucose } \\
\text { utilized } \\
(s)(\mathrm{g} / \mathrm{l})\end{array}$ \\
\hline 1 & 0.25 & 16.97 & 11.39 & 12.41 & 78.68 \\
2 & 0.5 & 19.68 & 14.95 & 10.35 & 81.56 \\
3 & 0.75 & 21.56 & 19.09 & 6.96 & 85.04 \\
4 & 1 & 26.85 & 20.93 & 5.26 & 86.47 \\
5 & 1.25 & 25.97 & 18.37 & 3.53 & 88.56 \\
6 & 1.5 & 24.44 & 16.78 & 3.02 & 88.97 \\
\hline
\end{tabular}

Table 10 Effect of agitation rate on L-lysine production by immobilized cells

\begin{tabular}{llllll}
\hline Sl. no & $\begin{array}{l}\text { Agitation } \\
\text { rate }(\mathrm{rpm})\end{array}$ & $\begin{array}{l}\text { Lysine } \\
\text { conc. } \\
(p)(\mathrm{g} / \mathrm{l})\end{array}$ & $\begin{array}{l}\text { Biomass } \\
(x)(\mathrm{g} / \mathrm{l})\end{array}$ & $\begin{array}{l}\text { Residual } \\
\text { glucose } \\
\text { conc. }(\mathrm{g} / \mathrm{l})\end{array}$ & $\begin{array}{l}\text { Glucose } \\
\text { utilized } \\
(s)(\mathrm{g} / \mathrm{l})\end{array}$ \\
\hline 1 & 100 & 23.63 & 13.45 & 10.22 & 80.87 \\
2 & 150 & 26.09 & 15.79 & 8.41 & 83.65 \\
3 & 200 & 31.58 & 17.72 & 4.07 & 86.03 \\
4 & 250 & 28.49 & 16.77 & 7.48 & 84.16 \\
5 & 300 & 27.94 & 17.39 & 6.82 & 83.27 \\
6 & 350 & 25.78 & 16.94 & 10.67 & 81.42 \\
7 & 400 & 23.33 & 15.09 & 11.45 & 80.64 \\
\hline
\end{tabular}

Table 11 Optimized fermentation parameters for free cells and immobilized cells of C. glutamicum MH 20-22 B

\begin{tabular}{lll}
\hline Fermentation conditions & $\begin{array}{l}\text { Free cells of } \\
\text { C. glutamicum } \\
\text { MH 20-22 B }\end{array}$ & $\begin{array}{l}\text { Immobilized cells } \\
\text { of C. glutamicum } \\
\text { MH 20-22 B }\end{array}$ \\
\hline Fermentation time & $72 \mathrm{~h}$ & $96 \mathrm{~h}$ \\
$\mathrm{pH}$ & 7.5 & 7.5 \\
Temperature & $30{ }^{\circ} \mathrm{C}$ & $30{ }^{\circ} \mathrm{C}$ \\
Glucose concentration & $80 \mathrm{~g} / 1$ & $90 \mathrm{~g} / 1$ \\
Airflow rate & $1.25 \mathrm{vvm}$ & $1.0 \mathrm{vvm}$ \\
Aeration rate & $300 \mathrm{rpm}$ & $200 \mathrm{rpm}$ \\
\hline
\end{tabular}


immobilized cells of $C$. glutamicum $\mathrm{MH}$ 20-22 B. Table 11 illustrates the optimized fermentation parameters for free cells and immobilized cells of C. glutamicum $\mathrm{MH}$ 20-22 B. The results obtained here indicate that L-lysine can be produced efficiently by immobilized growing $C$. glutamicum MH 20-22 B cells. By comparison with the results obtained with free cells, there is a significant improvement concerning the accumulation of L-lysine by immobilized growing cells.

\section{Conclusion}

To improve the production rate of L-lysine, free and immobilized cell of C. glutamicum MH 20-22 B were analyzed under various process conditions. It was observed that the optimum values of fermentation time, $\mathrm{pH}$, temperature, glucose concentration, airflow rate and aeration rate were $96 \mathrm{~h}, 7.5,30{ }^{\circ} \mathrm{C}, 90 \mathrm{~g} / \mathrm{l}, 1.0 \mathrm{vvm}$ and $200 \mathrm{rpm}$, respectively, by immobilized cells. whereas in case of free cells the optimum values were $72 \mathrm{~h}, 7.5,30^{\circ} \mathrm{C}, 80 \mathrm{~g} / \mathrm{l}$, $1.25 \mathrm{vvm}$ and $300 \mathrm{rpm}$. Immobilized C. glutamicum $\mathrm{MH}$ 20-22 B cells exhibited greater L-lysine production of $31.58 \mathrm{~g} / \mathrm{l}$ than free cells, which produced $26.34 \mathrm{~g} / \mathrm{l}$ of $\mathrm{L}-$ lysine. The results obtained here indicate that L-lysine can be produced efficiently by immobilized growing $C$. glutamicum MH 20-22 B cells by comparison with the results obtained with free cells in a stirred tank bioreactor.

Acknowledgments The authors are grateful to NATCO for all their encouragement in the fermentation studies.

Conflict of interest We declare that there is no conflict of interest regarding the publication of this article.

Open Access This article is distributed under the terms of the Creative Commons Attribution License which permits any use, distribution, and reproduction in any medium, provided the original author(s) and the source are credited.

\section{References}

Akashi S, Shibai H, Hirose Y (1979) Effect of oxygen supply on Llysine, L-threonine and L-isoleucine fermentations. Trends Biochem Sci 43:2087

Anastassiadis S (2007) L-Lysine Fermentation. Recent Pat Biotechnol 1(1):11-24

Araki K, Kato F, Aral Y, Nakayama K (1974) Histidine production by auxotrophic histidine analog-resistant mutants of Corynebacterium glutamicum. Agric Biol Chem 38:837

Becker MJ (1982) Product biosynthesis in continuous fermentation. Folia Microbiol 27:315-318

Bercovici D, Fuller MF (2007) Industrial amino acids in nonruminant animal nutrition. In: Wallace RJ, Chesson A (eds) Biotechnology in animal feeds and animal feeding. Wiley, Weinheim. doi:10. 1002/9783527615353.ch6
Broer S, Eggeling L, Kraemer R (1993) Strains of Corynebacterium glutamicum with different lysine productivities may have different lysine excretion systems. Appl Env Microbiol 59:316

Chinard FP (1952) Photometric estimation of proline and ormithine. J Biol Chem 199:91-95

Eggeling L (2007) L-Serine and Glycine. In: Amino acid biosynthesis pathway, regulation and metabolic engineering. Springer, Berlin, vol 5, pp 259-272

Ekwealor A, Obeta JAN (2005) Studies on lysine production by Bacillus megaterium. Afr J Biotechnol 4:633-638

Fechter WL, Dienst JH, Le Patourel JF (1997) US5684190

Guillout S, Rodal AA, Lessard PA, Sinskey AJ (2002) Methods for producing L-isoleucine. USA patent (US 6451564)

Hadj Sassi A, Fauvart L, Deschamps AM, Lebeault JM (1988) Fed batch production of L-lysine by Corynebacterium glutamicum. Biochem Eng J 1:85-90

Hilliger M, Haenel F, Menz J (1984) Influence of temperature on growth and L-lysine formation in Corynebacterium glutamicum. J Appl Microbiol 24:437-441

Hirose Y, Shibai H (1985) L-Glutamic acid fermentation. Compr Biotechnol 3:595-600

Ikeda M (2003) Amino acid production processes. Adv Biochem Eng Biotechnol 79:1-35

Ikeda M (2006) Towards bacterial strains overproducing L-tryptophan and other aromatics by metabolic engineering. Appl Microbiol Biotechnol 69:615-626

Ikeda M, Katsumata R (1992) Metabolic engineering to produce tyrosine or phenylalanine in a tryptophan producing Corynebacterium glutamicum strain. Appl Environ Microbiol 58:781-785

Jetty A, Gangagni Rao A, Sarva Rao B, Madhavi G, Ramakrishna SV (2005) Comparative studies of ALR and FBR for streptomycin production by immobilized cells of Streptomyces sp. Chem Biochem Eng 19:179-184

Kase H, Nakayama K (1975) Fermentation production of L-methionine and regulation of L-methionine biosynthesis in Corynebacterium glutamicum. Agric Biol Chem 39:153-160

Kim BH, Seong bL, Mheen TI, Han MH (1981) Studies on microbial penicillin amidase, optimization of the enzyme production from Escherichia coli. Korean J Appl Micobiol Bioeng 9:29

Kinoshita S, Udaka S, Shimono M (1957) Amino acid fermentation. I. Production of L-glutamic acid by various microorganism. J Gen Appl Microbiol 3:193-205

Kinoshita S, Nakayama K, Akita S (1958) Taxonomical study of glutamic acid accumulating bacteria, Micrococcus glutamicus. Agric Chem Soc Jpn 22:176

Leuchtenberger W, Huthmacher K, Drauz K (2005) Biotechnological production of amino acids and derivatives: current status and prospects. Appl Microbiol Biotechnol 69(1):1-8

Marek PJ, Kierstan M, Coughlan MP (1985) Immobilized cells and enzymes. Practical approaches UK. Ireland press limited, Ireland, pp 43-44

Michalski HJ, Krzystek L, Blazczyk R, Jamroz T, Wieczorek A (1984) The effect of mean residence time and aeration intensity on the L-Lysine production in a continuous culture. In: Third Europian congress on biotechnology, München, FRG, vol 2. Verlag Chemie, Weinheim, pp 527-532

Morris DL (1948) Microbial physiology. Wiley, New York

Nakamura T, Nakayama T, Koyama Y, Shimazaki K, Miwa H, Tsuruta M, Tamura K, Tosaka O (2000) L-Lysine fermentation (US20006025169)

Nakayama K, Kase H (1974) Studies on L-threonine fermentation and Mechanism of L-threonine and L-lysine production by analogresistant mutants of Corynebacterium glutamicum. Agric Biol Chem 38:993-1000 
Neish AC (1952) Analytical methods for bacterial fermentations. Report 46-8-3, 2nd revision. National Research Council of Canada, Saskatoon, Canada

Patek M (2007) Branched chain amino acids biosynthesis pathways, regulation and metabolic engineering. Springer, Heidelberg

Pfefferle W, Moeckel B, Bathe B, Marx A (2003) Biotechnological manufacture of L-lysine. In: Scheper $\mathrm{T}$ (ed) Advances in biochemical engineering, vol 79. Springer, Berlin, p 59

Ruklisha M, Paegle L, Denina I (2007) L-Valine biosynthesis during batch and fed batch cultivations of Corynebacterium glutamicum: relationship between changes and bacterial growth rate and intracellular metabolism. Progr Biochem 42:634-640

Shah AH, Hameed A, Khan GM (2002) Fermentative production of Llysine, bacterial fermentation. J Med Sci 2:152-157

Udaka S (1960) Screening methods for microorganisms accumulating metabolites and its use in the isolation of Micrococcus glutamicus. J Bacteriol 79:754

Wang JS, Kuo YC, Chang CC, Liu YT (1991) Optimization of culture conditions of L-lysine fermentation by Brevibacterium species. Nat Biotechnol 68:154-159 